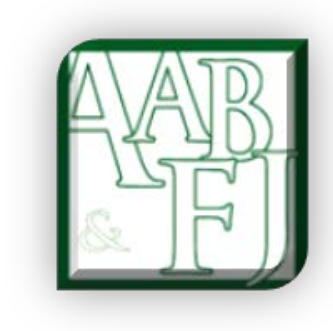

\title{
The Audit Committee Characteristics and Earnings Quality: Evidence from Jordan
}

\author{
Allam Mohammed Mousa Hamdan ${ }^{1}$, Sabri Maher Sabri Mushtaha ${ }^{2}$ and Abd Almuttaleb \\ Mohammed Al-Sartawi ${ }^{3}$
}

\begin{abstract}
The aim of the paper is to investigate the relationship between audit committee characteristics and earnings management. Samples in the study included 50 industrial companies listed on the Amman Stock Exchange ASE. Two models were used to measure earnings quality: one which depends on earnings continuity as an indication of quality, and one which depends on the decrease of discretionary accruals of quality, using pooled data regression for the two tests (Ordinary Least Squares OLS and Binary Logit). The study found that there was an influence of some standard characteristics of audit committee on earnings quality.
\end{abstract}

Keywords: Audit Committee Characteristics; Earnings Quality; Amman Stock Exchange.

JEL Code: M40

\footnotetext{
${ }^{1}$ Associate Professor of Accounting, Head of Accounting and Economics Department, College of Business and Finance, Ahlia University, Kingdom of Bahrain. E-mail: allamh3@hotmail.com

${ }^{2}$ Assistant Professor of Accounting, Accounting Department, Faculty of Administrative and Economic Sciences, AL-Quds Open University, Palestine

${ }^{3}$ Assistant Professor of Accounting, Accounting Department, College of Business Administration and Finance, Ahlia University, Kingdom of Bahrain
} 


\section{Introduction}

Corporate governance has created significant changes in business environments in general, and in the accounting and auditing professions in particular. Interest in the role of audit committees has increased in the last few years because it is the tool of corporate governance, whose aim is to increase the questioning of the board of management and to increase the role of audit and its independence, after several financial failures of many local and international companies (Hamdan \& Mushtaha 2011). During the last years, there was, as well, an increasing organisational interest in the role of the audit committee in preparing financial reports (Martnez \& Fuentes 2007). The Wild (1994) study found that the credibility and fairness of financial reports issued by companies depends on the existence of an audit committee emerging from management councils of such companies, while Martnez and Fuentes (2007) found that an audit committee would be more active in the process of monitoring financial statements and limiting the differences between the management and the external auditor. This reduces the probability of the company receiving qualified opinions from the external auditor resulting from accounting errors or non-commitment to accounting standards.

Many countries and local and international vocational bodies now spend more effort to issue instructions and standards, which when adopted help restore credibility in the financial data declared. This also helps in activating the role of audit committees, which consolidates functioning and independence of the external auditor as an impartial party providing his opinion on the declared financial data fairly and objectively. One of these efforts is the recommendation of the Securities and Exchange Commission (SEC) and Exchange Commission, New York Stock Exchange (NYSE), and the National Association of Securities Dealers (NASDA), to form a Blue Ribbon Committee (BRC 1999) to be a natural reaction to the distortions in financial statements. These committees aimed to develop recommendations which help improve financial reports through consolidating their role. It also put down a series of qualities which should prevail in order to have an active audit committee. Such qualities include: size of committee, experience, financial knowledge of members, degree of their independence, and frequent meetings. In July 2002, the USA's Sarbanes-Oxley law was described by analysts to be the most significant and comprehensive American legislation since the forming of the SEC because of its impact on general companies and independent accountants. Some of the large reforms that the legislation included were the right of declaration, submission of financial reports by foreign general companies' corporate governance, and monitoring of accounting auditors. According to article 301 of the legislation, a special part was made stressing the duties and formation of an audit committee, in order to secure the safety and credibility of the report of the external auditor who might be subjected to managerial pressure. As for Jordan, much legislation supporting corporate governance was issued in order to regulate the work of audit committees in Jordanian companies. Our study attempts to discuss such legislation related to audit committees to ensure their application by Jordanian companies. Afterwards, the study tries to test the role played by audit committees in improving earnings quality. Qaraqish (2009) sees that earnings quality means the absence of such earnings, from estimations and substitutes by which the company tries to get a targeted net return.

The real contribution of the current study to existing literature is to provide additional evidence about the relationships between audit committee characteristics and earnings quality from developing countries. It also uses the new models to measure the earnings quality in Jordanian corporations, which was not used in previous studies in this environment (such as 
Qaraqish 2009). The importance of this study is to look for relationships between the audit committee characteristics and earnings quality in Jordan, which regularly takes steps towards the regulatory and legislative structure to support economic development. This distinguishes this study from other studies conducted in the United States and Australia.

The following sections of the study discusses previous studies and study methodology, including the study sample, study models, hypotheses, and methods of measuring variables. These will be followed by a discussion of the the empirical results as well as a conclusion and recommendations.

\section{Literature Review}

\subsection{Audit Committees}

The concept of audit committees differs according to the goals, functions, and responsibilities assigned to them. Al-Thuneibat (2006) defined it as the committee that is composed of nonexecutive directors in the establishment. The major goal behind forming the audit committee is to increase auditing quality and questioning of board of directors. Arens et al. (2009) defines it as a group of persons selected from members of the board of directors who are responsible for retaining independence of the auditor.

Many studies were concerned with checking qualities of audit committees as one of the tools of corporate governance, with many influences like controlling earnings management, or improving financial reports, and earnings quality. Hamdan and Mushtaha (2011) conducted a study with the aim of analyzing the relationship between the possibility of the company receiving an audit clean report and the characteristics of the audit committees of the industrial Jordanian companies listed in ASE. The findings of their study showed a positive impact for the size of the audit committee members on the report of external auditor. They also showed a negative impact for stock ownership of members of audit committees on the report of the external auditor. At the same time, the independence of (executive and non-executive) members of the audit committee or the number of meetings had no impact on the opinion of the external auditor. The study of Stewart and Munro (2007) from Australia focused on the results of frequent meetings on the audit committee. They determined that the presence of an audit committee, the number of its meetings and the auditor's attendance for such meetings reduces audit risks, and that the external auditor believes that the presence of an audit committee is an important factor in reducing substantial risks of auditing. They further determined that reducing such risks is also affected by frequent meetings of the audit committee and auditor's attendance of such meetings. Stewart and Munro also found no substantial influence of the audit committee, either on the tests conducted by external auditor or on the time spent by the external auditor and his team in the process of auditing. The audit committee helps in solving disputes and conflicts with the administration and that leads to more improvement in audit quality. However, there is a relationship between the possibility that the company receives qualified reports from the external auditor and the presence of the audit committee characteristics (independence, size, meeting times, and financial experience). In answering this question, Martinez and Fuentes (2007) applied this on Spanish companies listed in the stock exchange, which voluntarily formed an audit committee after the Spanish corporate governance code was issued in 1998 (known as the Olivencia Code). The findings of their study might be outlined as follows: ownership concentration affects the possibility of the company receiving a qualified report; the outcome of errors or noncommitment; the presence of the audit committee can never be of the factors related to the 
company conservative non-verified report; the presence of an audit committee doesn't reduce the probability of the company receiving a qualified report resulting from errors or non-commitment; and the size and independence of members of the audit committee are variables that have an important statistical impact on the company receiving a qualified report.

As for the ability of the audit committee to control earnings management, the study of Saleh et al. (2007) tried to evaluate the role of some qualities of the audit committee with regard to independence of committee members, its size, its frequency of meetings, and the experience and knowledge members of the committee have to monitor management behaviour. The practices related to earnings management of the general Malaysian joint-stock companies, and the conflict between managers and external auditors, might exist due to the choice of alternative accounting procedures related to earnings management. Some of the most important findings of the study are: absolute independence among members of an audit committee reduces the practices of earnings management in the Malaysian companies; and the companies whose members of audit committees are distinguished for experience, financial knowledge, professionalism, and frequent meetings have less practices of earnings management when compared to other companies. The study of Mazlina et al. (2006) tried to test the relationship between characteristics of the audit committee and those of the internal audit committee, to evaluate the contribution of internal auditors in auditing financial statements. It conducted that by designing and distributing a questionnaire to internal executive auditors in 76 general Malaysian companies listed in the financial market. The most important findings were: there was a positive relationship between the internal auditors' evaluation regarding their contribution in auditing financial statements and three audit committee characteristics: rate of independence of its members, knowledge and experience which the members have in fields of accounting and auditing and reviewing programs of internal auditor.

Results show that the most effective audit committees and good resources regulating internal auditing tend to be positively related to the evaluation of internal auditors in their contribution to external auditing. Sweiti (2006) endeavored to develop a model to consolidate the role of audit committees in Jordanian joint-stock companies for the purpose of strengthening the function and independence of external auditing. This would eventually lead to improved audit quality and increased credibility of the financial declared data, which helps consolidate the trust of the financial society in such data.

The study distributed a questionnaire to a randomly selected sample representing general Jordanian joint-stock companies. The sample included general managers, financial managers, and directors of internal and external auditors in the year 2005. Some of the most important findings of the study were that recently formed audit committees in the Jordanian corporations did not have the necessary requirements needed to effectively play their role, and did not have any significant impact on the effectiveness and independence of the external audit.

The study of Carcello and Neal (2003) focused on the relationship between audit committee independence and disclosure quality. The two researchers used the external auditor report, size of audit committee, and size of board of directors as control variables. The most important findings of the study were:

a) there was a significant positive relationship between the percentages of the independentmembers of the audit committee and the optimistic disclosure about the financial status of the company 
b)there was no statistical relationship between the size of both board of directors, audit committee and optimistic disclosure with regard to the status of financial notes and administrative discussions and analyses

c) there was a significant positive relationship between audit committee independence and financial reports quality

The study of Felo et al. (2003) on the relationship between audit committee characteristics "regarding: financial experience, independence, and committee size", and financial information quality, came up with the following findings:

a) there is an adverse relationship between the independence of audit committee members and financial deviations

b)a positive relationship exists between the financial experience of audit committee members and the quality of published financial information

c) there is apositive relationship between the sizes of audit committees and quality of financial information

Finally, the study of Al-Farah (2001) aimed to measure how active the audit committees were in the Jordanian corporations, from the viewpoint of directors of internal and external auditors. It also attempted to know the most important factors that help consolidate efficiency of such committees from the point of view of members of these audit committees. The study dealt with all the companies that have audit committees by the end of December 2000. The most important findings of the study were:

a) the audit committees of Jordanian companies were active from the viewpoint of internal auditing, but never from the viewpoint of the external auditors

b) some of the factors that consolidate the role of audit committees are: the financial or accounting background of one member of the audit committee; the independence of members of the audit committee; the existence of written evidence

\section{The regulations of Jordanian audit committees}

Jordan tried to enact legislation to support corporate governance, one of which is the stock exchange law no. 76; 2002. That law obliges all Jordanian joint-stock companies to form an audit committee consisting of three non- executive members from the company's board of directors. The duties and responsibilities of such committees are determined by the instructions issued by the board which comply with article (46). It also secures banking law no. (28) 2000 which obliges all Jordanian banks to form audit committees. Articles no. (32) and (33) of this law determine responsibilities and duties. Instruction no. (1) 1998 issued by the Amman Stock Exchange requested all Jordanian joint-stock companies to form audit committees. Modern disclosure instructions were issued and were put into effect at the beginning of 2004. Article no. (15) explained how to form the audit committee, determining its duties and responsibilities. The most recent concept of audit committees in Jordanian milieu was the one issued by the Amman Stock Exchange stating the "directory of governance rules of companies listed in Amman Stock Exchange 2008", which stipulates that the audit committee should consist of non-executive members of the board of directors who shouldn't be less than three. Two of them at least should be independent members, one of whom chairs the committee. All members of the committee should be equipped with knowledge of financial and accounting affairs. Decisions of the committee are taken by absolute majority of members. It should also put down written procedures to regulate its duties and commitments with the approval of the board of directors. It 
has the right to ask for legal, financial, administrative or technical opinion from any external consultant.

\subsection{Earnings Quality}

\section{Various definitions of earnings quality}

Investors' concerns with earnings quality increased during the last decade after many international companies announced non-authentic and temporary earnings as part of their quarterly reports. Thus, investors became more cautious in considering net earnings. Qaraqish (2009) and Ohlson and Feltham (1995) define earnings quality as the investor's ability to predict future abnormal earnings depending on recent data. But Qaraqish (2009) sees that the real earnings quality is the one honestly and justly announced by the companies as their actual earnings. In other words, the announced earnings of companies have a substantial financial existence which is void of exaggeration or probability figures. Many of the definitions of earnings quality revolve around the two previous ones. Earnings quality is the ability of the present earnings to provide a real picture about the company and its ability to survive in the future. The significance of earnings quality stems from the earnings on which many parties depend when they take their decision (Dechow 1884).

Bagava (2006) believes that earnings quality is considered an important factor in the financial statement and is used as a guidance to decision making. Depending on earnings of low quality leads to an inappropriate management of fortune (Schipper \& Vincent 2003). Understanding earnings quality plays an important role in the process of financial analysis; earnings of high quality help financial analysts in analyzing three basic sides of information. These arethe present functional performance of the company, future functional performance, and value of the company (Dechow \& Schrand, 2004). In addition, earnings quality might be used as an indicator of dividends. Farinha (2007) ascertains that there is a relationship between earnings quality and dividends: the possibility of dividends by companies increases as the quality itself improves, and the amount of such dividends also increases. There are different views regarding the concept of earnings quality: while some use earnings continuity as a standard of its quality as explained by Altamuro \& Beatty (2006), the continuity of earnings refers to the relationship between the present earnings with the future ones. As earnings are divided into cash flows and accruals, quality earnings means that cash flows are more than accruals (Sloan 1996). Others indicate that earnings quality is better once free from earnings management practices: the less the discretionary accruals are, the better the quality is (Francis et al. 2004; Dechow \& Dichev 2002; Al-Sharif 2008). Different styles for measuring earnings quality led to different evaluations, where the same company might be given a higher or lower quality level according to the earnings quality form adopted (Abdelghany 2005).

\section{Previous studies:}

Baxter and Cotter (2009) studied the formation and characteristics of audit committees and their impact on improving earnings quality in a sample of Australian companies before obligatory requirements were introduced to audit committees in 2003. The results of that study showed that forming an audit committee reduces earnings management, but did not reduce accrual estimation errors. The study also showed that there was a significant relation between the financial experience of members of audit committee and earnings quality improvement. The other qualities of the audit committee did not have any relatively significant relationship with earnings quality. Various studies provided many other factors influencing earnings quality. Teitel and 
Machuga (2010) found that supporting rules of corporate governance contributed to the improvement of earnings quality. Altamuro and Beatty (2006) also found that internal control quality played a role in improving earnings quality. In comparing public firms with private ones, Givoly et al. (2010) found that the former were more conservative in their financial reports than the latter, and that their management practice through using normal accruals was less. Consequently, earnings quality in these firms was better than that in the private ones and that was due to the desire of the directors of public firms to avoid litigation risk and agency costs. With regard to the relationship between auditing quality and improving earnings quality, Hamdan and Abu Ijeila (2010) found that auditing quality of audit offices in Jordan did not contribute to limit earning management practices in Jordan industrial companies subject to auditing. Such offices never played a role in increasing earning qualities in Jordanian industrial companies. But Teitel and Machuga's (2010) study on the impact of the application of Code of Best Governance Practices in the presence of external auditors from highly qualified audit offices found that it helps improve earnings quality. Balsam et al. (2003) studied the impact of one of the auditing quality professional auditor's specialisation on discretionary accruals and found that the companies which used professional specialised auditors had less discretionary accruals compared to the companies which used less professionally specialised auditors. Therefore, one can claim that companies with professionally specialised auditors enjoy a higher level of earnings quality.

\section{Research Design and Methodology}

\subsection{Study Sample}

The study sample included all Jordanian industrial corporations listed in ASE which met the conditions of having all necessary data available, and having never been merged or delisted through the period of the study. 50 companies met such conditions from 2004-2009. We focus on the six-year window 2004-2009 because the Code of audit committee was voluntary in 2002 and portions of the Code became mandatory in the Securities Market Law in 2004. The corpus of the study is composed of all Jordanian industrial corporations listed on the ASE 94; the final sample consists of 50 companies, the sample-selection procedure is summarised in Table 1.

\section{Table 1: Sample selection}

\begin{tabular}{lrrrr}
\hline \multicolumn{1}{c}{ Sector } & $\begin{array}{c}\text { Listed } \\
\text { companies }\end{array}$ & & $\begin{array}{c}\text { Excluded } \\
\text { companies }\end{array}$ & $\begin{array}{c}\text { Study } \\
\text { sample }\end{array}$ \\
\cline { 1 - 2 } \cline { 4 - 4 } Pharmaceutical and Medical Industries & 7 & 2 & 5 \\
Chemical Industries & 14 & 7 & 7 \\
Paper and Cardboard Industries & 5 & 1 & 4 \\
Printing and Packaging & 2 & 1 & 1 \\
Food and Beverages & 16 & 10 & 6 \\
Tobacco and Cigarettes & 3 & 2 & 1 \\
Mining and Extraction Industries & 16 & 9 & 7 \\
Engineering and Construction & 12 & 2 & 10
\end{tabular}


AABFJ | Volume 7, no. 4, 2013

\begin{tabular}{lrrrr}
\cline { 2 - 4 } Electrical Industries & 6 & 4 & 2 \\
Textiles, Leathers and Clothings & 10 & 3 & 7 \\
Glass and Ceramic Industries & & 3 & 3 & 0 \\
\hline Total & $\mathbf{9 4}$ & $\mathbf{4 4}$ & $\mathbf{5 0}$ \\
\cline { 1 - 3 } & &
\end{tabular}




\subsection{Technique of Measuring Variables and Study Models}

\subsubsection{Measuring Independent Variables: Characteristics of Audit Committees}

The characteristics of the audit committees we studied were based on many past studies. Table 2 shows the measuring of independent variables.

\section{Table 2: Measuring of audit committees characteristics}

\begin{tabular}{|c|c|c|}
\hline Variable & Label & Measurement \\
\hline \multicolumn{3}{|l|}{ Characteristics of Audit Committees: } \\
\hline Audit Committee Size & ACSize & $\begin{array}{l}\text { This was measured through members of that committee elected by board of } \\
\text { directors. }\end{array}$ \\
\hline Audit Committee Independence & ACIndep & $\begin{array}{l}\text { With reference to the instructions of Jordanian disclosure, we find that ASE } \\
\text { requires an audit committee to stem from the board of directors and should } \\
\text { totally consist of non-executive members. Therefore, we will adopt this quality } \\
\text { to determine the independence of audit committee. This committee that } \\
\text { totally comprises non-executive members is given (1), but if not all the } \\
\text { members were non-executive, it is given (0). }\end{array}$ \\
\hline Number of Audit Committee Meetings & ACActivity & $\begin{array}{l}\text { According to the directory of corporate governance of companies listed in ASE } \\
\text { and Jordanian disclosure instructions, the audit committee must meet } \\
\text { regularly. These meetings should not be less than four every year. Thus, this } \\
\text { variable was measured through the number of annual meetings the } \\
\text { committee holds. }\end{array}$ \\
\hline $\begin{array}{l}\text { Financial Experience of Audit Committee } \\
\text { Members }\end{array}$ & ACExper & $\begin{array}{l}\text { The financial experience of the audit committee measured by dividing the } \\
\text { number of qualified members in accounting financial and banking } \\
\text { management by all members. }\end{array}$ \\
\hline $\begin{array}{l}\text { Percentage of Common Stocks Owned by Audit } \\
\text { Committee }\end{array}$ & ACOwner & $\begin{array}{l}\text { This was measured through the percentage of ownership of the audit } \\
\text { committee for company stocks. }\end{array}$ \\
\hline
\end{tabular}




\subsubsection{Measuring of Dependent Variable: Earnings Quality}

This study adopted two of the commonest models for measuring earnings quality which are the Richardson et al. (2005) model, and the Jones (1991) model as modified by Dechow et al. (1995). We used the two models to confirm the results.

\section{The first model}

There are different interpretations for earnings quality, and among them is the use of earnings continuity as an indicator of earnings quality (Altamuro \& Beatty 2006; Schipper \& Vincent 2003). Sloan (1996) explained that earnings quality implies continuity of cash flows more than accruals continuity. Richardson et al. (2005) developed a model to determine the range of earnings continuity in the future as the following equation no. 2 shows.

$$
R O I_{i, t+1}=\gamma_{0}+\gamma_{1}\left(R O I_{i, t}-\text { TACC }_{i, t}\right)+\gamma_{2} \text { TACC }_{i, t}+v_{i, t+1}
$$

Where:

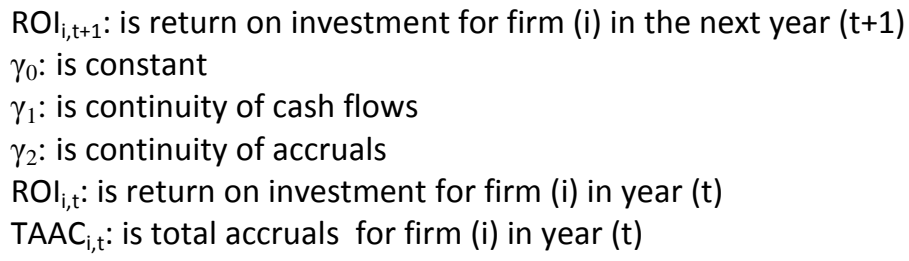

Earnings quality means that next year's earnings represented in returns on investment $\left(\mathrm{ROA}_{\mathrm{i}, \mathrm{t}+1}\right.$ dependent variable in equation no. 1) is affected by earnings of the current year represented in $\gamma_{1}$ coefficient more than total accruals represented in the $\gamma_{2}$ coefficient. Then, our hypothesis in the previous equation is $\gamma_{2}-\gamma_{1}<0$ which indicates continuity of earnings in the coming years is more than the continuity of accruals as $\gamma_{2}<\gamma_{1}$ known as earnings quality. To concentrate on the continuity of accruals in earnings quality; we modify the equation to become equation no. 2 as follows:

$$
R O I_{i, t+1}=\rho_{0}+\rho_{1} R O I_{i, t}+\rho_{2} T_{A C C_{i, t}}+v_{i, t+1}
$$

This equation might be rewritten regarding accruals continuity in equation no.1 as follows:

$$
R O I_{i, t+1}=\gamma_{0}+\gamma_{1}\left(R O A_{i, t}\right)+\left(\gamma_{2}-\gamma_{1}\right) \text { TACC }_{i, t}+v_{i, t+1}
$$

As $\rho_{1}=\gamma_{1}$ and $\rho_{2}=\left(\gamma_{2}-\gamma_{1}\right)$, this evaluation saves us the direct evaluation for $\gamma_{1}-\gamma_{2}$ in equation no. 1 . Our first hypothesis is still $\rho_{2}<0$ as it is more negative in accruals representing earnings that imply the presence of high quality earnings. This model will be given the symbol (EQR). 


\section{The second model}

The second measure of earnings quality is the use of the absolute value of discretionary accruals. To extract discretionary accruals, we used the modified version of the Jones (1991) model adjusted by Dechow et al. (1995). This model will be given the symbol (EQJones), which is one of the most used methods in measuring earnings management that is used in the opposite direction of measuring earnings quality. As earning management means the intentional interference in preparing financial reports by managers to achieve personal interests (Schipper 1989), thus the opportunistic earnings management negatively affects earnings quality; this implies that the increase of management earnings is followed by a reduction in earnings quality (Baxtert \& Cotter 2009). Calculating discretionary accruals can be done through the following steps:

a) total accruals evaluation which is the difference between net income and operating cash flows, according to the previous equation no. 1

b) slope evaluation $\beta_{1}, \beta_{2}, \beta_{3}$ in the following linear model:

$$
\frac{\operatorname{TACC}_{i, t}}{A_{i, t-1}}=\alpha+\beta_{1}\left(\frac{1}{A_{i, t-1}}\right)+\beta_{2}\left(\frac{\Delta R E V_{i, t}-\Delta R E C_{i, t}}{A_{i, t-1}}\right)+\beta_{3}\left(\frac{P P E_{i, t}}{A_{i, t-1}}\right)+\ell_{i, t}
$$

\section{Where:}

TACC $_{i, t}$ : is the total accruals of firm (i) in year ( $t$ )

$A_{i, t-1}$ : is the total assets of firm (i) at the end of year ( $t-1$ )

$\triangle R E V_{i, t}$ : is the change in revenues of firm (i) between years ( $t$ ) and (t-1)

$\triangle R E C_{i, t}$ : is the change in receivables of firm (i) between years ( $t$ ) and (t- 1$)$

$P P E_{i, t}$ : is the level of fixed assets of firm (i) in year ( $t$ )

$\mathrm{l}_{\mathrm{i}, \mathrm{t}}$ : random error

c) Normal accruals evaluation, using, $\beta_{1}, \beta_{2}, \beta_{3}$ derived from equation no. 6 as follows:

$$
N A C C_{i, t}=\beta_{1}\left(\frac{1}{A_{i, t-1}}\right)+\beta_{2}\left(\Delta R E V_{i, t}-\Delta R E C_{i, t}\right)+\beta_{3}\left(P P E_{i, t}\right)
$$

Where:

NACC $i, t$ is the normal accruals of firm (i) in year $(t)$

d) After evaluating total and normal accruals, discretionary accruals (Abnormal), resulting from the pursuit of earnings management, are computed as follows:

$$
A N A C C_{i, t}=\text { TACC }_{i, t}-N A C C_{i, t}
$$

The reduction of absolute value of discretionary accruals reflects a decrease in opportunistic earnings management, which eventually leads to the increase of earnings qualities reducing dishonesty, and thus expressing the real status of the company. 


\subsubsection{Measuring of Control Variables}

Big 5 Jordanian audit firms

DeAngelo (1981) inferred that the big audit firms were more able to provide audit services of high quality than other offices. Such a thing qualifies them to monitor administration behaviour, contribute to the prevention of distortions in financial statements, and increase earnings quality. To achieve its goals, this study depended on the division adopted by Faraj (2005) and Balhaj (2006) in classifying Jordanian audit firms into small and large ones. It determined the five big firms in Jordan and accordingly assigned (1) to refer to the companies whose financial reports are audited by the large firms, and the value (0) to refer to the companies whose financial statements are audited by small firms.

\section{Company size}

The variable of the company size was used as a controlling one to study the difference between the small and large companies with regard to earnings quality. Natural log of total assets was used to measure company size.

\section{Degree of financial leverage}

This percentage is used to evaluate the efficiency of financial policies adopted by company management, in addition to being one of the significant indicators that explain how suitable the financial published reports of joint-stock companies are (Matar 2006). As for the goals of this Study, it used the overall ratio of percentage of debts to assets to be an indication of financial leverage in the sample of this study.

\section{The percentage of the common stocks owned by members of the board of directors}

According to the agency theory, it was proposed that the dominance of members of the board of directors on higher levels of company stocks will lead to gain earnings of high quality with many privileges. This was emphasised by Qaraqish (2009) who found a positive relation between the stock ownership of members of the board of directors and earnings quality. Thus, our study included this variable through which the percentage of stock ownership of members of board of directors was measured.

\section{The external auditor turnover}

According to the study of Shokley (1982), the long relationship between the company and the external auditor may make the auditor non-creative and thus adopt less rigid audit techniques and depend on procedures and solutions of company without verification. The two researchers tended to measure the level of the auditor's turnover through the number of years of his work in auditing in companies.

\section{Auditor's specialisation in customer's industry}

This variable was listed among the controlling variables because it was believed that the auditor's specialisation in the customer's industry will lead to a better auditing quality. This consequently leads to increased administration monitoring and preventing manipulation of financial statements, thus leading to the betterment of earnings quality. Dummy value, 1 if the Auditor's Specialisation in Customer's Industry; 0 otherwise. 


\subsubsection{The Relation Between Characteristics of Audit Committees and Earnings Quality}

In our research on the relationship between audit committees and earnings quality, we measured earnings quality using two models at the first stage. While examining the relation between audit committees and earnings we designed two major models to measure this relation in which the dependent variable was the earning quality. Therefore, two linear models were created, each of which contains two measures of audit committees and a group of control variables, to control the relationship between the dependent and independent variables. Thus, the models used to represent the relation between audit committees and earnings quality are four in number.

\section{First Model}

In the first regression model the dependent variable "earnings quality" was measured by using the Richardson et al. (2005) model and expressed through the continuous variable $\left(\mathrm{EQRCV}_{\mathrm{i}, \mathrm{t}}\right)$ as follows:

$$
\begin{aligned}
\text { EQRCV }_{i, t} & =\beta_{0}+\beta_{1} \text { ACSize }_{i, t}+\beta_{2} \text { ACIndep }_{i, t}+\beta_{3} \text { ACActivity }_{i, t}+\beta_{4} \text { ACExper }_{i, t}+\beta_{5} \text { ACOwner }_{i, t} \\
& +\beta_{6} \text { Big }_{i, t}+\beta_{7} \text { Size }_{i, t}+\beta_{8} \text { FinLav }_{i, t}+\beta_{9} \text { Maown }_{i, t} \\
& +\beta_{10} \text { EAprof }_{i, t}+\beta_{11} \text { EATurn }_{i, t}+\varepsilon_{i, t} \quad \ldots \ldots \ldots \text { (7) }
\end{aligned}
$$

\section{Where:}

EQRCV $_{i, t}$ : is a continuous variable: dependent variable: earnings quality measured through (Richardson et al., 2005) model for the company (i) in the year ( $t$ )

ACSize $_{i, t}$ : is number of audit committee members for the company (i) in the year ( $t$ )

$A C$ Indep $p_{i, t}$ : is dummy variable, audit committee independence for the company (i) in the year ( $t$ )

ACActivit $y_{i, t}$ is number of audit committee meetings for the company $(i)$ in the year $(t)$

ACExper ${ }_{i, t}$ : is dummy variable, the financial experience of members of the audit committee for the company (i) in the year $(\mathrm{t})$

ACOwner ${ }_{i, t}$ : is the percentage of common stocks owned by audit committee for the company (i) in the year ( $t$ )

Big5 $_{i, t}$ : is control variable, dummy variable, size of the audit firm with the value of 1 if audited by Jordanian Big5 and 0 otherwise for the company (i) in the year $(t)$

Size $_{i, t}$ : is control variable, the company size measured by natural log of total assets for the company (i) in the year (t)

FinLav ${ }_{i, t}$ : control variable, financial leverage ratio, total debts/total assets of the company (i) in the year ( $t$ )

Maown $n_{i, t}$ : control variable, The percentage of the Common Stocks Owned by Members of the Board of Directors for the company (i) in the year ( $t$ )

EAprof $_{\mathrm{i}, \mathrm{t}}$ : control variable, specialization of external auditor in the customer's industry. It is a dummy variable given (1) if the auditor is specialised in the customer's industry, or else given (0) for the company (i) in year (t)

EATurn $_{\mathrm{i}, \mathrm{t}}$ : control variable, external auditor turnover, measured by number of years of work for the external auditor of the company (i) at the end of the year ( $t$ )

$\varepsilon_{\mathrm{i}, \mathrm{t}}$ : random error.

\section{Second Model}

In the second regression model, the dependent variable "earnings quality" was measured by the Richardson et al. (2005) model, and was expressed through the dummy variable $\mathrm{EQRDV}_{\mathrm{i}, \mathrm{t}}$ as follows: 
AABFJ | Volume 7, no. 4, 2013

$$
\begin{aligned}
\text { EQRDV }_{i, t} & =\beta_{0}+\beta_{1} \text { ACSize }_{i, t}+\beta_{2} \text { ACIndep }_{i, t}+\beta_{3} \text { ACActivity }_{i, t}+\beta_{4} \text { ACExper }_{i, t}+\beta_{5} \text { ACOwner }_{i, t} \\
& +\beta_{6} \text { Big5 }_{i, t}+\beta_{7} \text { Size }_{i, t}+\beta_{8} \text { FinLav }_{i, t}+\beta_{9} \text { Maown }_{i, t} \\
& +\beta_{10} \text { EAprof }_{i, t}+\beta_{11} \text { EATurn }_{i, t}+\varepsilon_{i, t} \quad \ldots \ldots \ldots . .(8)
\end{aligned}
$$

Where:

EQRDV $_{i, t}$ : is a dummy variable: the dependent variable 'earnings quality' is measured by using (Richardson et al., 2005) model, (3) for high earnings quality (2) of doubtful earnings quality (1) for lower earnings quality of the company $(\mathrm{i})$ in the year $(\mathrm{t})$.

\section{Third Model}

In the third regression model, the dependent variable "earnings quality" was measured by the absolute value of discretionary accruals elicited through the Jones (1991) model as follows:

$$
\begin{aligned}
\text { EQJones }_{i, t} & =\beta_{0}+\beta_{1} \text { ACSize }_{i, t}+\beta_{2} \text { ACIndep }_{i, t}+\beta_{3} \text { ACActivity }_{i, t}+\beta_{4} \text { ACExper }_{i, t}+\beta_{5} \text { ACOwner }_{i, t} \\
& +\beta_{6} \text { Big }_{i, t}+\beta_{7} \text { Size }_{i, t}+\beta_{8} \text { FinLav }_{i, t}+\beta_{9} \text { Maown }_{i, t} \\
& +\beta_{10} \text { EAprof }_{i, t}+\beta_{11} \text { EATurn }_{i, t}+\varepsilon_{i, t} \quad \ldots \ldots \ldots \text { (9) }
\end{aligned}
$$

\section{Where:}

EQJones $s_{i, t}$ is a continuous variable: the dependent variable 'earnings quality' was measured by Jones (1991) model for the company (i) in the year ( $t$ )

\section{Fourth Model}

In the fourth regression model, the dependent variable "earnings quality" was measured by the absolute value of the discretionary accruals elicited by Jones (1991) model and explained through the dummy variables as follows:

$$
\begin{aligned}
& \text { EQJonesDV }_{i, t}=\beta_{0}+\beta_{1} \text { ACSize }_{i, t}+\beta_{2} \text { ACIndep }_{i, t}+\beta_{3} \text { ACActivity }_{i, t}+\beta_{4} \text { ACExper }_{i, t}+\beta_{5} \text { ACOwner }_{i, t} \\
&+\beta_{6} \text { Big5 }_{i, t}+\beta_{7} \text { Size }_{i, t}+\beta_{8} \text { FinLav }_{i, t}+\beta_{9} \text { Maown }_{i, t} \\
&+\beta_{10} \text { EAprof }_{i, t}+\beta_{11} \text { EATurn }_{i, t}+\varepsilon_{i, t} \quad \ldots \ldots \ldots \text { (10) }
\end{aligned}
$$

Where:

EQJonesDV $\mathrm{i}_{\mathrm{i}, \mathrm{t}}$ : is a dummy variable, the dependent variable 'earnings quality' was measured by Jones (1991) model,

(1) for low quality earnings (2) for doubtful earnings quality and (3) for high earnings quality of the company (i) in the year $(t)$ 


\section{Empirical Results and Discussion of Findings}

\subsection{Description Statistical of Study Variables}

\subsubsection{Description of Continuous Variables}

\section{Size of the audit committee}

From 3 we notice that the average size of a committee is three members, while the largest number of any committee is four. These results emphasize to the administration that the audit committee should not be very big, as that might lead to a decrease in coordination and problem solving, in addition to not being able toperform the duties in a perfect manner (Martinez \& Fuentes 2007). As a result, the Jordanian corporations committed themselves to the minimal size the committee must have in compliance with the Jordanian rules of corporate governance and legislations. This is what the study of Mayalah (2008) arrived at when conducting the study in a Jordanian environment.

\section{Financial experience of members of the audit committee}

It was found that $40 \%$ of the members of the study sample have financial experience with slight differences from one year to another. It was also noticed that audit members in some companies do not have any financial experience, while all members in some other ones have that experience. We can conclude that most of the Jordanian industrial companies abide by the rules of corporate governance with respect to the financial experience that minimally one of the members must have. This goes in line with the opinion that the experience one member has in corporate governance and financial reports preparation, along with knowledge in auditing, will most likely help understand the attitude of the auditor and his evaluations in order to side with him when conflict emerges with company management (Dezoort \& Salterio 2001).

\section{The annual number of meetings of the audit committee}

Table 3 shows that the audit committee of the study sample meets four times a year on average. The highest number of meetings for the companies was five a year, and the least was three. This shows that Jordanian industrial companies abide by the governance laws regarding the number of meetings of the audit committee.

Table 3: Descriptive statistics for 50 industrial Jordanian listed companies during 2004-2009

$$
\text { Panel A: Continuous variables }
$$

\begin{tabular}{cccccc}
\hline Variable & Year & Mean & SD & Minimum & Maximum \\
\hline AC Members & 2004 & 3.043 & 0.206 & 3 & 4 \\
& 2005 & 3.042 & 0.202 & 3 & 4 \\
& 2006 & 3.041 & 0.200 & 3 & 4 \\
& 2007 & 3.041 & 0.200 & 3 & 4 \\
& 2008 & 3.042 & 0.202 & 3 & 4 \\
AC Experience & 2009 & 3.044 & 0.208 & 3 & 4 \\
& 2004 & 0.403 & 0.259 & 0 & 1 \\
\hline
\end{tabular}




\begin{tabular}{|c|c|c|c|c|c|}
\hline & 2006 & 0.432 & 0.262 & 0 & 1 \\
\hline & 2007 & 0.432 & 0.262 & 0 & 1 \\
\hline & 2008 & 0.434 & 0.265 & 0 & 1 \\
\hline & 2009 & 0.434 & 0.271 & 0 & 1 \\
\hline \multirow[t]{6}{*}{ AC Meeting } & 2004 & 4.196 & 0.542 & 3 & 5 \\
\hline & 2005 & 4.229 & 0.425 & 4 & 5 \\
\hline & 2006 & 4.204 & 0.645 & 3 & 5 \\
\hline & 2007 & 4.143 & 0.456 & 3 & 5 \\
\hline & 2008 & 4.229 & 0.472 & 3 & 5 \\
\hline & 2009 & 4.178 & 0.442 & 3 & 5 \\
\hline \multirow[t]{6}{*}{ ACOwn } & 2004 & 8.631 & 16.015 & 0 & 68.85 \\
\hline & 2005 & 10.277 & 17.965 & 0 & 73.58 \\
\hline & 2006 & 11.789 & 20.027 & 0 & 98.61 \\
\hline & 2007 & 11.826 & 16.758 & 0 & 68.85 \\
\hline & 2008 & 12.222 & 17.174 & 0 & 68.85 \\
\hline & 2009 & 14.370 & 19.474 & 0 & 79.15 \\
\hline \multirow[t]{6}{*}{ Company Size } & 2004 & $29,342,925$ & $78,077,897$ & 560,000 & $413,000,000$ \\
\hline & 2005 & $30,927,269$ & $76,857,839$ & 450,258 & $406,000,000$ \\
\hline & 2006 & $34,467,122$ & $75,385,919$ & 784,000 & $386,000,000$ \\
\hline & 2007 & $59,738,663$ & $167,000,000$ & 430,303 & $916,000,000$ \\
\hline & 2008 & $72,645,856$ & $185,000,000$ & 800,000 & $1,080,000,000$ \\
\hline & 2009 & $27,680,673$ & $43,238,763$ & $1,000,000$ & $240,000,000$ \\
\hline \multirow[t]{6}{*}{ Leverage } & 2004 & 32.192 & 22.290 & 1.820 & 85.910 \\
\hline & 2005 & 29.812 & 23.041 & 2.310 & 88.010 \\
\hline & 2006 & 29.934 & 21.912 & 1.690 & 92.770 \\
\hline & 2007 & 31.561 & 24.627 & 0.890 & 99.480 \\
\hline & 2008 & 26.927 & 19.797 & 0.790 & 93.930 \\
\hline & 2009 & 27.315 & 20.329 & 0.310 & 88.300 \\
\hline \multirow[t]{6}{*}{ MAOWN } & 2004 & 15.960 & 20.875 & 0.000 & 89.250 \\
\hline & 2005 & 16.694 & 20.176 & 0.000 & 89.250 \\
\hline & 2006 & 16.299 & 20.591 & 0.000 & 89.250 \\
\hline & 2007 & 16.234 & 19.631 & 0.000 & 89.250 \\
\hline & 2008 & 14.253 & 17.522 & 0.000 & 89.250 \\
\hline & 2009 & 13.200 & 16.391 & 0.000 & 89.250 \\
\hline \multirow[t]{6}{*}{ Auditor Turnover } & 2004 & 5.283 & 1.311 & 2.000 & 6.000 \\
\hline & 2005 & 5.313 & 1.291 & 2.000 & 6.000 \\
\hline & 2006 & 5.449 & 1.022 & 3.000 & 6.000 \\
\hline & 2007 & 5.429 & 1.080 & 2.000 & 6.000 \\
\hline & 2008 & 5.250 & 1.407 & 2.000 & 6.000 \\
\hline & 2009 & 5.133 & 1.618 & 1.000 & 6.000 \\
\hline
\end{tabular}


Hamdan, Mushtaha \& AI-Sartawi | Audit Committee Characteristics: Jordan

Panel B: Dichotomous variables

\begin{tabular}{cccc}
\hline Variable & Year & Frequency of 1's & Frequency of 0's \\
\hline AC Indep. & 2004 & $35(70 \%)$ & $15(30 \%)$ \\
& 2005 & $35(70 \%)$ & $15(30 \%)$ \\
& 2006 & $36(72 \%)$ & $14(28 \%)$ \\
& 2007 & $38(76 \%)$ & $12(24 \%)$ \\
& 2008 & $35(70 \%)$ & $15(30 \%)$ \\
Big5 & 2009 & $35(70 \%)$ & $15(30 \%)$ \\
& 2004 & $34(68 \%)$ & $16(32 \%)$ \\
& 2005 & $34(68 \%)$ & $16(32 \%)$ \\
& 2006 & $34(68 \%)$ & $16(32 \%)$ \\
& 2007 & $34(68 \%)$ & $16(32 \%)$ \\
& 2008 & $31(62 \%)$ & $19(38 \%)$ \\
& 2009 & $30(60 \%)$ & $15(40 \%)$ \\
& 2004 & $22(44 \%)$ & $11(22 \%)$ \\
& 2005 & $23(46 \%)$ & $11(22 \%)$ \\
& 2006 & $23(46 \%)$ & $11(22 \%)$ \\
& 2007 & $23(46 \%)$ & $11(22 \%)$ \\
& 2008 & $23(46 \%)$ & $11(22 \%)$ \\
& 2009 & $23(46 \%)$ & $11(22 \%)$ \\
\hline
\end{tabular}

Panel C: Dummy variables of earnings quality

\begin{tabular}{ccccc}
\hline Variable & Year & High EQ & Doubtful EQ & Low EQ \\
\hline EQRDV & 2004 & $24(48 \%)$ & $1(2 \%)$ & $25(50 \%)$ \\
& 2005 & $25(50 \%)$ & $0(0 \%)$ & $25(50 \%)$ \\
& 2006 & $24(48 \%)$ & $1(2 \%)$ & $25(50 \%)$ \\
& 2007 & $24(48 \%)$ & $1(2 \%)$ & $25(50 \%)$ \\
& 2008 & $22(44 \%)$ & $0(0 \%)$ & $28(56 \%)$ \\
& 2009 & $24(48 \%)$ & $1(2 \%)$ & $25(50 \%)$ \\
& 2004 & $46(92 \%)$ & $0(0 \%)$ & $04(08 \%)$ \\
& 2005 & $43(86 \%)$ & $0(0 \%)$ & $07(14 \%)$ \\
& 2006 & $43(86 \%)$ & $0(0 \%)$ & $07(14 \%)$ \\
& 2007 & $41(82 \%)$ & $0(0 \%)$ & $09(18 \%)$ \\
& 2008 & $45(90 \%)$ & $0(0 \%)$ & $05(10 \%)$ \\
& 2009 & $41(82 \%)$ & $0(0 \%)$ & $09(18 \%)$ \\
\hline
\end{tabular}




\section{The ratio of common stocks owned by audit committees}

We notice that the average amount of stocks the audit committee owns is $11 \%$. The maximum percentage of ownership of the company's stock was 98\%. In other companies the audit committee did not own any stocks of the delisted one. This explains why members of the audit committee are selected from those who are influential in decision making because of their owned stocks in the company.

\section{Company size}

Regarding size of the company which is a controlling variable, we notice that the mean of company sizes listed in the study sample increased from one year to another, but decreased in 2009, possibly due to the international financial crisis.

\section{Financial leverage}

Financial leverage is one of the control variables. The mean of the sample study in this respect was 34\%. This reflects a big difference because the Jordanian industrial companies depend on foreign financing when financing their assets.

\section{Ratio of the common stocks owned by boards of directors}

This too is one of the control variables. We found that the ratio of stocks owned by members of boards of directors was $15 \%$. Thus boards of directors as a whole owned $89 \%$ of the stocks, which represent the highest percentage in the study sample. In some companies the board of directors does not own any stock percentage and this complies with the Al-Sharif (2008) study in his description of the ownership of the board of directors in the Jordanian milieu.

\section{The average turnover of the auditor}

Annual turnover is measured by the years of experience the auditor spent in the same company. It was found that the average years of the auditor's work in the same company was five out of six-the period the study covers. In other words, the auditor continues for $83 \%$ of his auditing in the same company. The data revealed that there were some auditors who lasted auditing the same company throughout the period of the study. The shortest period of work for the auditor in the same company was one year.

\subsubsection{Description of Dichotomous Variables}

\section{Independence of members of audit committees}

Table 3 part B shows that $70 \%$ of the study sample has audit committee members who are distinguished for their independence the first and the second years of the study. This percentage increased to $76 \%$ the third year and went down to $70 \%$ for the rest of the years. Meanwhile we found that few companies of the sample study, the audit committees in them, never met independence standard and those covered $29 \%$ of the companies.

\section{Large Jordanian auditing firms}

As for the variable of the Big 5 and whether the company was audited by one of the biggest of these five in Jordan, we noticed through the descriptive analysis that $66 \%$ of the sample companies were audited through six years. This means that the big audit firms in Jordan have a control over auditing for the majority of the general industrial joint- stock companies.

\section{Auditor's specialization in customer's industry}


Part B of table 3 shows that $44-46 \%$ of the sample companies are audited by auditors specialised in their industry. This increases the opportunity to monitor company performance which might help in improving earnings quality.

\subsubsection{Description of Earnings Quality}

The study used two methods to measure earnings quality: the Richardson et al. (2005) model and the Jones (1995) model. In Table 3 part C, earnings quality was divided into three parts: high earnings quality, low, and doubtful. By using the model of Richardson, et al. (2005), we notice that $44-48 \%$ of Jordanian industrial company returns are distinguished by high quality, while 50$56 \%$ of the returns of these companies are distinguished by low quality, and quite a few amount of such returns are of doubtful quality. When using the model of Jones (1995), the results showed that the highest percentage $82-92 \%$ of the returns of the Jordanian industrial companies were distinguished by high quality while the rest of the companies were of low quality. There were no returns of doubtful quality, according to the Jones (1995) model. Despite the differences of results, they show that the returns of the Jordanian industrial companies are distinguished by a reasonable quality, and that implies the ability to predict the future and highlight the status quo of the company.

\subsection{Testing Study Hypotheses}

This study depends on two models for measuring the relationship between audit committees and earnings quality. Each of these two models is divided into two sub-models. The first explains the relationship between the dependant variable "earnings quality" with the continuous one. The second model highlights the relationship between the dependant variable with the dummy one. The main hypothesis is "There is an impact with statistical significance of the audit committee characteristics (size of committee, degree of independence, financial experience of its members, number of meetings, committee ownership of stocks) on improving earnings quality of Jordanian corporations listed in ASE". This hypothesis generates sub-hypotheses which tackle the impact of every characteristic of the audit committee on the betterment of earnings quality. The following are tests of study sub-hypotheses.

\subsubsection{Testing the first sub-hypothesis}

This hypothesis aims to test the impact of the size of the audit committee on improvement of earnings quality. The first sub-hypotheses can be written as null-form:

$\mathrm{H}_{01}$ : Size of the audit committee has no impact, with statistical significance, on the improvement of earnings quality

Larger audit committees better monitor the preparation of financial reports and improve earnings quality (Lin \& Yang 2006). Size of audit committee is positively related to the quality of financial reports (Hamdan and Mushtaha 2011; Felo et al. 2003). Size also helps reduce cheating and forgery in financial statements (Huang 2005). As for the role of the size of audit committees of Jordanian industrial companies in improving earnings quality, from Table 4 it is noticed that the variable (size of audit committee ACSize) is negatively related, with statistical significance to the earnings quality measured by Richardson et al. (2005). This model considers earnings quality to be a continuation of future returns. As for the second model in Table 5, it doesn't show any relationship, with statistical significance, between the size of audit committee and earnings quality measured by the modified Jones (1995) model. This model considers earnings quality to 
be the returns which include the minimal amount of discretionary accruals. This result differs with findings of Qaraqish (2009) which found no relationship between the size of audit committee and the improvement of earnings quality. This difference goes back to the models used in measuring earning quality in this study and that of Qaraqish (2009), besides the difference of the sample and period of study. The inappropriate increase in the size of audit committee might lead to a decrease in the efficacy of activity of the audit committee due to the waste in costs and muddling in work (Al-Farah 2001).

\subsubsection{Testing the second sub-hypothesis}

This sub-hypothesis attempts to answer whether or not the independence of members of the committee contributes to the competence which improves earnings quality. The second subhypotheses can be written as null-form:

$\mathrm{H}_{02}$ : Degree of independence of the audit committee has no impact, with statistical significant, on the improvement of earnings quality

The basic notion is that their independence and control of administrative work improves performance and earnings quality (Qaraqish 2009) and reduces practices of earnings management (Saleh et al. 2007; Carcello et al. 2006). However, our study didn't find any influence for the dependence of members of the audit committee on improving earnings quality, whether the model used was that of Richardson, et al. (2005) or the modified Jones (1995) model. Independent members of the audit committees in Jordanian industrial companies never contributed to the improvement of the quality of financial reports (Hamdan \& Mushtaha 2011). The independence that some members of the committee have is in form, not in execution, because there is an apparent financial or family connection with members of audit administration that appointed them. We were surprised to find that the audit committee in one of the companies consisted of three brothers! For such reasons, independence of the committee never left any impact on earnings quality. Such a result complies with that of Lin and Yang (2006), which also never found any influence of that independence of members, with any statistical significance, on earnings quality and financial reports. The study of McMullen and Raghunandan (1996) found that the standard of independence of members of the audit committee, whether executive or nonexecutive, mostly reduces the role of the committee. Such a thing affects its supervisory and controlling roles.

\subsubsection{Testing the Third Sub-hypothesis}

The third sub-hypothesis focuses on the influence of financial experiences of audit committee members on improving earnings quality. The third sub-hypotheses can be written as null-form:

$\mathrm{H}_{03}$ : The financial experience of members of the audit committee has no impact, with statistical significant, on improvement of earnings quality

In Tables 4 and 5 we notice that there is statistical significance for the "AC Experience" variable only in the second sub-model of the first model in which the earnings quality was illustrated through dummy variables measured by the Richardson, et al. (2005) model. With regard to the influence of financial experience, this study complies with many, like those of Hamdan and Mushtaha (2011), which found that the financial experience of audit committee members had a positive influence on the quality of financial reports. 
Table 4: Pooled regression results to first model

\begin{tabular}{|c|c|c|c|}
\hline Variable & $\begin{array}{l}\text { Predicted } \\
\text { sign }\end{array}$ & $\begin{array}{c}\text { Model EQR } \\
\text { Ordinary Least Squares }\end{array}$ & $\begin{array}{c}\text { Model EQRDV } \\
\text { Binary Logit }\end{array}$ \\
\hline AC Members & $+/-$ & $\begin{array}{c}2.475 \\
(0.015)\end{array}$ & $\begin{array}{l}-3.603 \\
(0.000)\end{array}$ \\
\hline AC Indep. & + & $\begin{array}{l}-0.472 \\
(0.638)\end{array}$ & $\begin{array}{c}1.289 \\
(0.197)\end{array}$ \\
\hline AC Experience & + & $\begin{array}{l}-0.463 \\
(0.644)\end{array}$ & $\begin{array}{l}-3.167 \\
(0.002)\end{array}$ \\
\hline AC Meetting & $+/-$ & $\begin{array}{l}-2.353 \\
(0.020)\end{array}$ & $\begin{array}{c}2.294 \\
(0.022)\end{array}$ \\
\hline ACOwn & - & $\begin{array}{c}5.509 \\
(0.000)\end{array}$ & $\begin{array}{l}-2.998 \\
(0.003)\end{array}$ \\
\hline Big5 & + & $\begin{array}{c}6.431 \\
(0.000)\end{array}$ & $\begin{array}{l}-4.265 \\
(0.000)\end{array}$ \\
\hline Company Size & + & $\begin{array}{l}-4.738 \\
(0.000)\end{array}$ & $\begin{array}{c}3.620 \\
(0.000)\end{array}$ \\
\hline Leverage & + & $\begin{array}{c}0.075 \\
(0.941)\end{array}$ & $\begin{array}{l}-3.274 \\
(0.001)\end{array}$ \\
\hline MAOwn & - & $\begin{array}{c}0.721 \\
(0.473)\end{array}$ & $\begin{array}{l}-2.142 \\
(0.032)\end{array}$ \\
\hline Auditor Turnover (AT) & $+/-$ & $\begin{array}{c}0.489 \\
(0.626)\end{array}$ & $\begin{array}{c}0.423 \\
(0.672)\end{array}$ \\
\hline Prof. & + & $\begin{array}{l}-2.100 \\
(0.038)\end{array}$ & $\begin{array}{c}0.786 \\
(0.432) \\
\end{array}$ \\
\hline $\begin{array}{l}F \text {-statistic } \\
p \text {-value }\end{array}$ & & $\begin{array}{c}8.616 \\
(0.000)\end{array}$ & \\
\hline R-Square & & 0.439 & \\
\hline Adjusted R-Square (Akaike) & & $(0.388)$ & 0.705 \\
\hline
\end{tabular}

OLS: $t$-test (top), $p$-value (bottom), two-tailed. Binary logit: $z$-test (top), $p$-value (bottom)

$t$-Critical: at df 39 , and confidence level of $99 \%$ is 2.390 and level of $95 \%$ is 1.671 and level of $90 \%$ is 1.296

$z$-Critical: at confidence level of $95 \%$ is 1.650

F-Critical (df for denominator $n-\beta-1=50-11-1=38$ ) and ( $d f$ for numerator $=\beta=11$ ) and confidence level of $99 \%$ is 2.730 and confidence level of $95 \%$ is 2.040 
AABFJ | Volume 7, no. 4, 2013

Table 5: Pooled regression results to second model

\begin{tabular}{|c|c|c|c|}
\hline Variable & $\begin{array}{l}\text { Predicted } \\
\text { sign }\end{array}$ & $\begin{array}{c}\text { Model EQJones } \\
\text { Ordinary Least Squares }\end{array}$ & $\begin{array}{c}\text { Model EQJonesDV } \\
\text { Binary Logit }\end{array}$ \\
\hline \multirow[t]{2}{*}{ AC Members } & $+/-$ & 1.452 & 0.142 \\
\hline & & (0.149) & $(0.887)$ \\
\hline \multirow[t]{2}{*}{ AC Indep. } & + & -0.684 & -0.364 \\
\hline & & $(0.495)$ & $(0.716)$ \\
\hline \multirow[t]{2}{*}{ AC Experience } & + & -1.665 & -0.543 \\
\hline & & $(0.098)$ & $(0.587)$ \\
\hline \multirow[t]{2}{*}{ AC Meetting } & $+/-$ & 1.207 & -0.255 \\
\hline & & $(0.230)$ & (0.799) \\
\hline \multirow[t]{2}{*}{ ACOwn } & - & -0.205 & -1.877 \\
\hline & & $(0.838)$ & $(0.061)$ \\
\hline \multirow[t]{2}{*}{ Big5 } & + & -0.867 & 1.190 \\
\hline & & $(0.388)$ & $(0.234)$ \\
\hline \multirow[t]{2}{*}{ Company Size } & + & 1.989 & 0.490 \\
\hline & & (0.049) & $(0.624)$ \\
\hline \multirow[t]{2}{*}{ Leverage } & + & -1.838 & 0.622 \\
\hline & & $(0.068)$ & $(0.534)$ \\
\hline \multirow[t]{2}{*}{ MAOwn } & - & 1.291 & -1.084 \\
\hline & & (0.199) & $(0.279)$ \\
\hline \multirow[t]{2}{*}{ Auditor Turnover (AT) } & $+/-$ & 1.161 & 0.768 \\
\hline & & $(0.248)$ & $(0.442)$ \\
\hline \multirow[t]{2}{*}{ Prof. } & + & -0.730 & 0.546 \\
\hline & & $(0.467)$ & $(0.585)$ \\
\hline F-statistic & & 2.997 & \\
\hline$p$-value & & (0.001) & \\
\hline R-Square & & 0.213 & \\
\hline Adjusted R-Square (Akaike) & & 0.142 & 0.884 \\
\hline
\end{tabular}

The study of Saleh et al. (2007) found that the companies that had audit committees, whose members are distinguished by financial experience, knowledge, and professionalism, are more able to put an end to the practices of earnings management, manipulations, and deception in financial statements. The study of McMullen and Raghunandan (1996) also found that companies which did not encounter any problems in their financial reports most likely had audit committees with professional accounting experience more than the ones that receive conservative reports and suffer from many problems in their financial reports. The studies of 
Bryan et al. (2004) and Qin 2007 confirmed that the financial and professional experience the members had was positively related to the quality of financial reports. It also had a contrarian connection with distorted financial reports and earnings management (Huang 2005; Yang \& Krishnan 2005). This result goes in line with the findings of past studies which found that the financial experience of audit committee members had an impact on the improvement of earnings quality (Qaraqish 2009; Baxter \& Cotter 2009; Xie et al. 2003; Choi et al. 2004).

\subsubsection{Testing the Fourth Sub-hypothesis}

The fourth sub-hypotheses can be written as null-form:

$\mathrm{H}_{04}$ : Number of meetings of the audit committee has no impact, with statistical significant, on the improvement of earnings quality

The Blue Ribbon Committee (BRC) in its ten recommendations submitted on the audit committee, disregarded the number of meetings of that committee. This omission was because the committee didn't find any absolute impact on the number of meetings in the companies' control or on the improvement of financial reports quality (Hamdan \& Mushtaha 2011). Many of the studies like those of Lin and Yang (2006) confirmed that there was no effect from the number of meetings of the audit committee on the quality of the financial reports. The study of Rahman and Ali (2006) also confirmed that there was no decisive evidence to prove that there was any effect from the number of meetings of the committee on earning quality as exemplified in the reduction of illegal earnings management practices. In our study, we did not find any impact of the number of meetings of the audit committee on earnings quality exemplified in the reduction of discretionary accruals in returns as Table 5 shows. Such a finding complies with the two studies of Qaraqish) (2009) and Baxter and Cotter (2009), who did not find any impact of the number of meetings of the committee on the improvement of earnings quality. But in Table 4 , we notice that the number of meetings had a positive impact, with statistical significance, on improving earnings quality as found in earnings continuity. This result differs from the findings of other studies.

\subsubsection{Testing the Fifth Sub-hypothesis}

The fifth sub-hypothesis tested the influence of the ratio of ownership of the stocks of the audit committee on earnings quality. The fifth sub-hypotheses can be written as null-form:

$\mathrm{H}_{05}$ : Ownership of stocks by members of the audit committee has no impact, with statistical significant, on the improvement of earnings quality

The study of Hamdan and Mushtaha (2011) noticed that such ownership is negatively related to the financial reports quality and positively connected with fraud and manipulation with financial statements, in addition to the absence of commitment to accounting standards (Martinez \& Fuentes 2007), and the illegal practices of the earnings management (Yang \& Krishnan 2005). The findings of our study go along with this study for we found both that ownership of audit committee of company stocks is negatively related, with statistical significance, to earnings quality demonstrated through future continuity of earnings, and is also negatively connected, with no statistical significance, to earnings quality demonstrated through low discretionary accruals of earnings. Such a finding goes along with the studies of Qaraqish 2009; Beasly 1996) which stated that the opportunity of deception in the financial statement decreases with the presence of external auditors who are not members of company owners. The direct financial interests of members of the audit committee deprive them the credibility of preventing administration distortions of financial statements (Wright 1990). 
AABFJ | Volume 7, no. 4, 2013

\subsubsection{Testing the Main Hypothesis}

The main hypothesis tests the role of the overall characteristics of audit committee on earnings quality:

EarningsQuality $\int_{n}^{300}$ ACSize; ACIndep; ACActivity; ACExper; ACOwner

Four models were used to test this hypothesis. In two of these models earnings quality was illustrated through continuous variables. The Ordinary Least Squares (OLS) test was used in testing. In the other two models earnings quality was illustrated through dummy variables; the Binary Logit test was used as well. By having a look at the two models 2 and 3, one can notice that the Adjusted $\mathrm{R}^{2}$ model which tests earnings quality, as being a continuity of earnings in the future using the model of Richardson, et al. (2005), is bigger than the Adjusted $\mathrm{R}^{2}$ of the second model, which tests the earnings quality through the decrease of discretionary accruals in both. This was discovered through using the adjusted Jones (1995) model. Such a finding shows that the first model best represents the relationship between characteristics of audit committee and earnings quality. This reinforces the finding that the Akaike value of the first model using dummy variables to express earnings quality is less than that of model two. When testing the main hypothesis, the audit committee characteristics' influence on earnings qualities can be arithmetically explained as: null hypothesis $\left(\mathrm{H}_{0}: \beta_{1}=\beta_{2}=\beta_{3}=\beta_{4}=\beta_{5}=0\right)$ against the alternative hypothesis one at least from $\left(\mathrm{H}_{\mathrm{a}}: \beta_{\mathrm{i}} \neq 0\right)$. We found that $F$-statistic is more in its critical value in the two models and $P$-value is less than $5 \%$. Thus, we can say that the collective characteristics of audit committees affect earnings quality.

\subsection{Testing Control Variables Large audit firms}

Our findings show that when financial statements are audited by big audit offices in Jordan, this helps returns continue in the future because such committees are highly qualified in their performance and can force companies to abide by accounting principles. Large auditing offices help improve the quality of financial reports (Hamdan \& Mushtaha 2011). These big auditing firms constitute a factor which helps reduce practices of earnings management that lead to issue a clean report (Johl, et al. 2007). In addition, external auditing conducted through large firms improves the credibility of financial statements. It also enforces a pressure on managers of companies to implement methods to care for such companies (Becker et al. 1998).

\section{Company size}

Many studies like those of Hamdan and Mushtaha (2011) and Change and Walter (1996) indicated that large companies enjoy a higher quality of financial reports than the smaller ones. Thus, they are less susceptible to failure and closure as they attract the concern of both shareholders and investors who have connections with financial markets. In our study, we found a positive relationship between the size of the company and the earnings quality measured by the model of Richardson, et al. (2005), while that relationship had no influence on the earnings quality measured by the adjusted Jones (1995) model.

\section{Financial leverage}

The study of Qaraqish (2009) found that the companies with minimal financial leverage had earnings of higher quality. In our study, we found the financial leverage had an impact on the 
earnings quality measured by the model of Richardson et al. (2005) as expressed through EQRDV $_{\mathrm{i}, \mathrm{t}}$. This effect was of a negative implication which means that the companies with minimal debts have a higher earnings quality and this complies with the findings of the study of Qaraqish (2009).

\section{The ratio of the stocks owned by the board of directors}

The findings of our study show that there is a negative relation between the ratio of stock ownership of board of directors and earnings quality, but this relation has no statistical significance except through the second sub-model. The ownership of stocks in the company by the board of directors may push them to give priority to their personal interests and falsify financial statements in order to achieve many goals such as bonus increment and other motives.

\section{External auditor's turnover}

We didn't find any relationship between the number of years of work for the external auditor and the earnings quality. This result is the one reached at by Knechel and Vanstraelen (2007) which found that there was no decisive evidence that the period of the external auditor's work in auditing in the same company reduced or increased the quality of financial reports.

\section{Specialisation of the auditor in the customer's industry}

The specialisation of the external auditor in the customer's industry will provide him with the knowledge and awareness of the company that qualifies him to monitor administration and to force it to abide by accounting principles that prevent distortion of financial statements. It is logical then to find that the variable EAprof $\mathrm{f}_{\mathrm{i}, \mathrm{t}}$ has a positive relationship with earnings quality, but this relationship has no statistical significance, except through Sub-model one in which quality was explained through the continuity of future returns.

\section{Conclusion and Recommendations}

Audit committees are one corporate governance mechanism which aims to coordinate the administration, external auditor, and monitoring of company performance in order to increase the influence of the corporate governance and secure transparency of financial disclosure.

Therefore, this study aims to explore the status of forming audit committees in the Jordanian industrial companies after a series of laws and legislation were issued by Jordan in this respect. It also studies the influence of the qualities of audit committees on earnings quality referred to in this study as the continuity of earnings in the future or for holding the lowest ratio of discretionary accruals. The data were collected from 50 Jordanian industrial companies from 2004-2009.

The findings of the study show that the Jordanian industrial companies meet the demands of forming auditing committees stipulated in Jordanian legislation. When testing its effect on earnings quality, we realised that the size of the audit committee is inversely connected with earnings quality measured by its ability to survive in the future. It is not suitable to increase the size of the audit committee to a great extent in order to perform perfectly; the size should be within the convenient range which makes it more effective.

We afterwards studied the role of independence of members of the audit committee in making them more able to improve earnings quality, but we didn't find any relationship between this variable and earnings quality. We found that members of the audit committees of Jordanian industrial companies were not independent. It was apparent that there was family and financial 
relationships between members and the boards of directors and that reduced their ability to control company's works and improve earnings quality; thus, we recommend that the authorities organizing works of companies in Jordan to enact legislation that increase independence of members of the audit committee. As for the financial experience of members of the audit committee to improve earnings quality, and despite meeting that condition by the industrial companies, we did not find any role to be played by it in improving earnings quality. This was because members of the committee did not have enough experience to face manipulations in financial statements and limit of earnings management: as a result, we recommend qualifying members of the audit committee to enable them perform their duties.

Regarding the role of the numbers of meetings of audit committees to make them more active in monitoring and improving their earnings quality measured through continuity, we found that the increase in the number of meetings helps improve earnings quality.

Finally, we also found that stock ownership by members of the audit committee reduces their independence and limits their ability to improve earnings quality. Based on these findings, we recommend limiting the ownership of audit committee.

In general, we recommend that organisers of works of Jordanian companies, like the stock market and government authorities, support the mechanism of corporate governance companies. This will secure more transparency in disclosures, reduce practices of earnings management, and improve earnings quality, for they all leave a significant impact on the economic decisions of many parties.

However, with a small sample size, caution must be applied, as the findings might not be generalisable. This research has thrown up many questions in need of further investigation, and it is recommended that further research be undertaken in the following areas: the impact of audit committee characteristics on enhancement of accounting conservatism; the relationship between audit committee characteristics and company performance; and factors affecting the earnings quality of Jordanian corporations.

\section{References}

Abdelghany, K 2005, 'Measuring the Quality of Earnings', Managerial Auditing Journal, vol. 20, no. 9, pp. 1001-1015. http://dx.doi.org/10.1108/02686900510625334

AL-Farah, A 2001, The effectiveness of audit committees in the Jordanian public shareholding companies: empirical study, University of Jordan, unpublished Master dissertation.

Al-Sharif, I, 2008, Quality of earnings and their relationship to corporate governance: An Empirical Study on the Industrial Sector Firms Listed at Amman Stock Exchange. Arab Academy for Banking and Financial Sciences, unpublished Ph.D dissertation.

Altamuro, J \& Beatty, A 2006, 'Do Internal Control Reforms Improve Earnings Quality?', Working Paper, www.ssrn.com.

Al-Thuneibat, A 2006, Audit in the light of the international auditing standards and regulations and local laws: the theory and application, first edition, Amman, Jordan University publications.

Arens, AA, Elder, RJ \& Beasley, MS 2009, Auditing and Assurance Services: An Integrated Approach, 13th Edition, New Jersey: Prentice Hall. 
Balhaj, S 2006, Factors affecting the voluntary disclosure of a practical study on public companies, Arab Academy for Banking and Financial Sciences, unpublished Ph.D dissertation.

Balsam, S, Krishnan, J \& Yang, J 2003, ‘Auditor Industry Specialization and Earnings Quality’, Auditing: A Journal of Practice and Theory, vol. 22, no. 2, pp. 71-97.

Baxter, P \& Cotter, J 2009, 'Audit committees and earnings quality', Accounting and Finance, vol. 49, no. 1, pp. 267-290. http://dx.doi.org/10.1111/j.1467-629X.2008.00290.x

Beasley, M 1996, 'An Empirical Analysis of the Relation between the Board of Director Composition and Financial Statement Fraud', Accounting Review, vol. 71, no. 4, pp. 443465.

Blue Ribbon Committee (BRC) 1999, Report and Recommendation of the Blue Ribbon Committee on Improving the Effectiveness of Corporate Audit Committees, New York, NY: New York Stock Exchange and National Association of Securities Dealers.

Bryan, D, Liu and Tiras, S 2004, 'The Influence of Independent and Effective Audit Committee on Earning Quality', Working Paper, State University of New York, Buffalo.

Carcello, J \& Neal, T 2003, 'Audit Committee Independence and Disclosure: Choice for Financially Distressed Firms’, Corporate Governance,vol. 11, no. 4, pp. 289-299. http://dx.doi.org/10.1111/1467-8683.00327

Carcello, JV, Hollingsworth, CW, Klein, A \& Neal, LT 2006, Audit Committee Financial Expertise, Competing Corporate Governance Mechanisms, and Earnings Management, February, available at www. ssrn.com.

Choi, JH, Jeon, K \& Prk, J 2004, 'The Role of Audit Committee in Decreasing Earning Management: Korean Evidence', International Journal of Accounting, Auditing and Performance Evaluation, vol. 1, no. 1, pp. 37-60. http://dx.doi.org/10.1504/IJAAPE.2004.004142

DeAngelo, L 1981, 'Auditor size and audit quality’, Journal of Accounting and Economics, vol. 3 (December), pp. 183-199. http://dx.doi.org/10.1016/0165-4101(81)90002-1

Dechow P, Sloan R \& Sweeney A 1995, 'Detecting Earnings Management', The Accounting Review, vol. 70, no.2, pp. 193-225.

Dechow, P \& Dichev, I 2002, 'The Quality of Accruals and Earnings: the Role of Accrual Estimation Errors', Accounting Review, vol. 77 (September), pp. 35-59. http://dx.doi.org/10.2308/accr.2002.77.s-1.35

Dechow, P \& Schrand, C 2004, Earnings Quality, The Research Foundation of CFA Institute.

Dezoort, F \& Salterio, S 2001, 'The Effect of Corporate Governance Experience and Financial Reporting and Audit Knowledge on Audit Committee Members Judgment', Auditing: A Journal of Practice and Theory, vol. 20, no. 2, pp. 31-47.

Faraj, A 2005, Assess the level of disclosure in interim financial reports of public shareholding companies of Jordan in light of the disclosure requirements of the progress of local and international, Arab Academy for Banking and Financial Sciences, unpublished Ph.D dissertation.

Farinha, J \& Moreira, A 2007, Dividends and Earnings Quality: The Missing Link?, Working Paper, University of Porto.

Felo A, Krishnamurthy, F \& Solieri S 2003, Audit Committee Characteristics and the Perceived Quality of Financial Reporting an Empirical Analysis, Working Paper, School of Graduate Professional Studies, Malven, www.ssrn.com. 
Francis, J, LaFond, R \& Schipper, K 2004, The Market Pricing of Earnings Quality, Working Papers, Duke Fuqua School of Business.

Givoly, D, Hayn, C \& Katz, S 2010, 'Does Public Ownership of Equity Improve Earnings Quality?', The Accounting Review, vol. 85, no. 1, pp. 195-225. http://dx.doi.org/10.2308/accr.2010.85.1.195

Hamdan, A, \& Abu Ijela, I 2010, 'Auditing Quality in Jordan and its Impact on Earnings Management and Earnings Quality’, The Arab Journal of Accounting, Accepted Paper.

Hamdan, A \& Mushtaha, S 2011, 'The Relationship Between Audit Committee Characteristics and Type of Auditor's Report: An Empirical Study on the Public Shareholding Industrial Companies Listed at Amman Bourse' The Arab Journal of Accounting, vol. 14, no. 1, pp. 109-163.

Huang, $\mathrm{H}$ 2005, The Effects of Audit Committee Characteristics on Investors Perception of Financial Reporting, Working Paper: Florida International University.

Johl, S, Jubb, C \& Houghton, K 2007, 'Earning Management and the Audit Opinion: Evidence from Malaysia’ Managerial Auditing Journal, vol. 22, no. 7, pp. 688-715. http://dx.doi.org/10.1108/02686900710772591

Jones, J 1991, 'Earnings Management during Import Relief Investigations', Journal of Accounting Research, vol. 29, no. 2, pp. 193-225. http://dx.doi.org/10.2307/2491047

Knechel, W \& Vanstraelen, A 2007, 'The Relationship between Auditor Tenure and Audit Quality Implied by Going Concern Opinions', Auditing: A Journal of Practice \& Theory, vol. 26, no. 1, pp. 113-131.

Lin, J \& Yang, J 2006, 'The Effect of Audit Committee Performance on Earnings Quality', Managerial Auditing Journal, vol. 21, no. 9, pp. 921-933. http://dx.doi.org/10.1108/02686900610705019

Lipton, M \& Lorsch, J 1992, 'A Modest Proposal for Improved Corporate Governance', Business Lawyer, vol. 48, no. 1, pp. 59-77.

Matar, M 2006, Recent trends in financial and credit analysis, methods, tools and practical uses, second edition, Amman: Darwael for publication and distribution.

Mayalah, S 2008, Factors affecting the improvement of the effectiveness of audit committees: applied study on the financial sector companies listed ASE, Arab Academy for Banking and Financial Sciences, unpublished Ph.D dissertation.

McMullen, D \& Raghunandan, K 1996, 'Enhancing Audit Committee Effectiveness', Journal of Accounting, vol. 182, no. 2, pp. 79-81.

Mushtaha, Sabri 2009 The Extent to Which the Characteristics of The Audit Committee Improves the Quality of Financial Reporting, PHD Research, Jordan.

Ohlson, J \& Feltham, J. 1995, 'Valuation and clean surplus accounting for operating and financial activities', Contemporary Accounting Research, vol. 11, no. 2, pp. 689-731. http://dx.doi.org/10.1111/j.1911-3846.1995.tb00462.x

Qaraqish, S 2009, The Effect of Audit Committee Characteristics on Earnings Quality An Empirical Study on the Industrial Sector Firms Listed at Amman Stock Exchange. Arab Academy for Banking and Financial Sciences unpublished dissertation.

Qin, B 2007, 'The Influence of Audit Committee Financial Expertise on Earnings Quality: U.S. Evidence', University of Groningen, www.ssrn.com

Rahman, R \& Ali, F 2006, 'Board, Audit Committee, Culture and Earning Management: Malaysian Evidence’, Managerial Auditing Journal, vol. 21, no. 7, pp. 783-804.

http://dx.doi.org/10.1108/02686900610680549 
Richardson, S, Sloan, R, Soliman, M \& Tuna, I 2005, 'Accrual Reliability, Earnings Persistence and Stock Prices', Journal of Accounting and Economics, vol. 39, no. 3, pp. 473-485. http://dx.doi.org/10.1016/j.jacceco.2005.04.005

Saleh, N, Iskandar, T \& Rahmat, M 2007, 'Audit Committee Characteristics and Earning Management: Evidence from Malaysia', Asian Review of Accounting, vol. 15, no. 2, pp. 147-163. http://dx.doi.org/10.1108/13217340710823369

Schipper, K 1989, 'Commentary on Earnings Management', Accounting Horizons, vol. 36, no. 1, pp. 91-102.

Schipper, K \& Vincent, L 2003, 'Earnings Quality’, Accounting Horizons, Supplement, pp. 97110. http://dx.doi.org/10.2308/acch.2003.17.s-1.97

Sloan, R 1996, 'Do stock prices fully reflect information in accruals and cash flows about future earnings?', The Accounting Review, vol.71, no.3, pp. 289-315.

Stewart, J \& Munro, L 2007, 'The Impact Of Audit Committee Existence and Audit Committee Meeting Frequency on the External Audit: Perceptions of Australian Auditors', International Journal of Auditing, vol. 11, no. 1, pp. 51-69. http://dx.doi.org/10.1111/j.1099-1123.2007.00356.x

Sweiti, M 2006, To develop a model of the role of audit committees in the Jordanian public shareholding companies and their impact on the effectiveness and independence of external audit, Arab Academy for Banking and Financial Sciences, unpublished Ph.D dissertation.

Teitel, K, \& Machuga, S 2010, 'The Interaction of Audit Firm Quality and the Mexican Code Of Best Corporate Practices On Earnings Quality’, Review of Business Research, vol. 10, no. 1, pp. 32-40.

Wild, J 1994, 'The Audit Committee and Earnings Quality', Journal of Accounting, Auditing and Finance, vol. 22, no. 1, pp. 247-276.

Wright, D 1996, Evidence on the Relation Between Corporate Governance Characteristics and the Quality of Financial Reporting, Working Papers, University of Michigan, www.ssrn.com

Xie, B, Davidson, W \& Dadalt, P 2003, 'Earning Management and Corporate Governance the Role of the Board and the Audit Committee', Journal of Corporate Finance, vol. 9, no. 3, pp. 295-316. http://dx.doi.org/10.1016/S0929-1199(02)00006-8

Yang, J \& Krishnan, J 2005, 'Audit Committee and Quarterly Earning Management', International Journal of Auditing, vol. 9, no. 3, pp. 201-219. http://dx.doi.org/10.1111/j.1099-1123.2005.00278.x

Yermack, D 1996, 'Higher Market Valuation of Companies with a Small Board of Directors', Journal of Financial Economics, vol. 40, no. 2, pp. 185-211.

http://dx.doi.org/10.1016/0304-405X(95)00844-5 
AABFJ | Volume 7, no. 4, 2013 